\title{
Comparative analysis of methods to identify road sections with high accidents risk: a case study of E67 Estonia-Latvia-Lithuania corridor
}

\author{
Maria Pashkevich ${ }^{1}$ and Anton Pashkevich ${ }^{2 *}$ \\ ${ }^{1}$ Estonian Road Administration, Teelise 4, Tallinn, 10916, Estonia \\ ${ }^{2}$ Politechnika Krakowska, ul. Warszawska 24, Krakow, 31-155, Poland
}

\begin{abstract}
E67 road is a strategically important part of a North Sea Baltic Core Network Corridor, connecting the three Baltic States with Finland, on the one hand, and with North Eastern Poland, on the other. Socalled Via Baltica corridor services more than 30000 vehicles per day being one of the major arteries for transit and heavy good vehicles transport in the region. Annually around 8000 road accidents with casualties occur in the three Baltic States with more than 500 fatalities a year. Relatively high road safety risk exposure requires more efficient management of infrastructure safety issues. The three Baltic States use either black spot management (BSM) or network safety management (NSM) or a combination of these two approaches to treat dangerous road sections of the network. In this article three methodologies used in the Baltic countries for dangerous road sections and spots identification were described. Quantitative analysis of dangerous sections/spots identified by the three methodologies was performed for the whole Via Baltica corridor to reveal the differences between the methods used.
\end{abstract}

\section{Introduction}

In its policy orientations on road safety European Commission [5] has set a goal of halving the overall number of road deaths in the European Union by 2020 starting from 2010. In 2011 the European Commission committed in the Transport White Paper [6] to following a vision to move close to zero road deaths in the EU by 2050. In line with the strategical documents mentioned before The United Nations also adopted its first formal target to halve the number of global deaths and injuries from road traffic accidents by 2020 within the Global Goals For Sustainable Development [12].

To enable mobility whilst minimise harm a wide range of countermeasures should be implemented tackling road users', vehicles' and infrastructure safety at a time. Road administrations responsible for public road network planning, construction and maintenance in European countries have to ensure, that relevant principles of safe management of infrastructure are properly implemented. EU Directive on infrastructure management requires the establishment and implementation of procedures relating to road

* Corresponding author: apashkevich@pk.edu.pl 
safety impact assessments, road safety audits, the management of road network safety and safety inspections by the Member States [2]. European Commission encourages road authorities to use these procedures not only to the TEN-T roads, but also on the whole road network.

Identification of road sections with a high accident concentration (so called "black spots") is one of the most efficient procedures to decrease the number of injury accidents. The efficiency of this measure has been assessed by different authors, which came to the conclusion that in general the effects depend very much on the countermeasures implemented. Black spot management implementation leads to decrease in the number of all road accidents by $11 \%$ and injury accidents by $29 \%$. Average cost-benefit ratio is around $2.8[10]$ and varies from $1.1(\mathrm{AADT}=5000)$ till $5.7(\mathrm{AADT}=30000)[3]$.

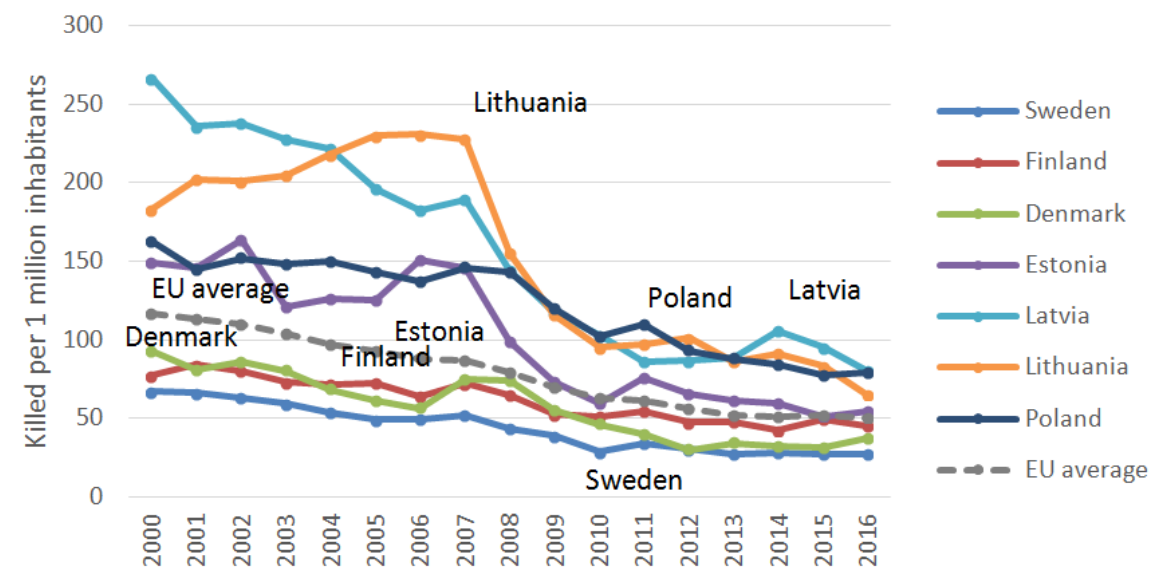

Fig. 1. Number of road fatalities per 1 million inhabitants in the Baltic states, neighbouring countries and EU average.

In 20168540 road accidents with casualties occurred in the three Baltic states resulting in 418 killed and more than 10350 injured people. Such results shows a great progress of these countries during the last 15 years in the field of road safety (Figure 1). This progress made since regaining independence is really enormous: road fatalities decreased by more than $80 \%$, thus traffic volumes and vehicle fleet increased to a great extent at the same time.

Striving for sustainable reduction of road fatalities and serious injuries on their transport network, Estonian (EE), Latvian (LV) and Lithuanian (LT) road administrations have been using either black spot management (BSM) or network safety management (NSM) or a combination of these two methods to treat dangerous road sections of the network. The goal of this article was to compare three approaches used in the Baltic countries for dangerous road sections and spots identification and to assess the differences between them analyzing E67 EE-LV-LT corridor.

\section{Data and methods}

\subsection{E67 Estonia-Latvia-Lithuania corridor as a study object}

European road E67 is a part of the International E-road network, connecting Prague (Czech Republic) and Helsinki (Finland) through Poland, Lithuania, Latvia and Estonia. The total length of the route is more than $1600 \mathrm{~km}$. Also E67 is a strategically important part of the 
trans-European transport network (TEN-T) and its North Sea-Baltic Core Network Corridor, in particular. The North Sea-Baltic Corridor connects ports of the North Sea (Antwerp, Rotterdam, Amsterdam, Bremen and Hamburg) with Eastern shore of the Baltic Sea (Klaipeda, Ventspils, Riga and Tallinn) as well as with Helsinki. The part of E67 from Tallinn (Estonia) to Warsaw (Poland), usually called as Via Baltica, is one of the most important arteries connecting the Baltic states. Besides that, Via Baltica road corridor serves road traffic coming from Finland and Russia and going to Central Europe. In view of these facts Estonia-Latvia-Lithuania part of E67 (altogether approx. $663 \mathrm{~km}$ ) was chosen for detailed study.

Annual average daily traffic (AADT) varies on the whole examined road from Tallinn to Lithuanian - Polish border from around 3000 till 45000 vehicles per day. The most intense traffic on the route is near the cities Tallinn, Riga and Kaunas and on intersections with other main roads like Klaipeda - Vilnius (E85), Panevežis - Vilnius (E272), Riga Pskov (E77), Riga - Moscow (E22) and Tallinn Ring road (part of E265). Via Baltica is a valuable artery for goods transportation, thus a share of heavy good vehicles reaches in some points $30 \%$ from all the traffic.

\subsection{Description of the methods used for BSM and NSM in the Baltic states}

Methods to identify accident concentration locations are a topic attracted an amount scientists $[1,7,8,9]$. Such research studies created a background for methodologies used by road authorities in different countries to treat dangerous road sections of the network.

In order to study the differences between the approaches towards dangerous sites' identification applied in EE, LV and LT, all three methodologies were described using a common check-list. Their summary is given below. Within the scope this study, the dangerous sections/spots on the whole E67 EE-LV-LT corridor were find out using methods of all Baltic states.

In LT black spot is a road stretch where within 4 years the number of road accidents with casualties corresponds to the condition:

$$
A_{\text {fact }}>A_{\text {min }},
$$

where

$A_{\text {fact }}$ - number of road accidents on a road stretch within 4 years;

$A_{\min }-$ minimum number of road accidents on a road within 4 year period $\left(A_{\min }=3\right)$.

Black spots are determined using a 500-meters long line or so called "sliding window" [11] and moving it from one road accident location to another. If the 500-meters line from accident covers 3 accidents ( $s 0 A_{\text {fact }}>A_{\min }$ ), this stretch is considered to be a black spot.

Identification of dangerous road sections in LV is schematically presented in Figure2. Comparing to LT methodology, 3-year road accidents data are used in LV. Road stretch is 1 $\mathrm{km}$ long and, in case of road junctions, an area of $150 \mathrm{~m}$ to each of the road junction's legs should be considered. Seriously injured person is a road accident participant, who spent more than $24 \mathrm{~h}$ in a hospital. Under B criterion, used road accidents include damage-only road accidents as well.

EE has recently shifted from BSM to a network safety ranking. Whole road network should be divided into homogeneous road sections and junctions and further on into homogeneous groups using road parameters (such as width and type of pavement, number of lanes, type of area, type of intersection etc.) and traffic data (traffic volume and speed limit) from the road database (see some examples of the groups in Table 1).

For each homogeneous road section and intersection level of safety should be calculated. For level of safety empirical Bayes approach is used: 


$$
E(\lambda / A)=\alpha \cdot \lambda+(1-\alpha) \cdot A,
$$

where

$E(\lambda / A)$ - expected number of accidents on a specific location;

$\alpha$ - weight between registered number and general expected number of accidents, $\alpha=1 /(1+\lambda / k)$;

$\lambda-$ general expected number of accidents estimated by accident models, as $\lambda$ homogeneous group average value of the specific group was used;

$A$ - registered number of accidents on the location;

$k$ - inverse value of the over dispersion parameter.

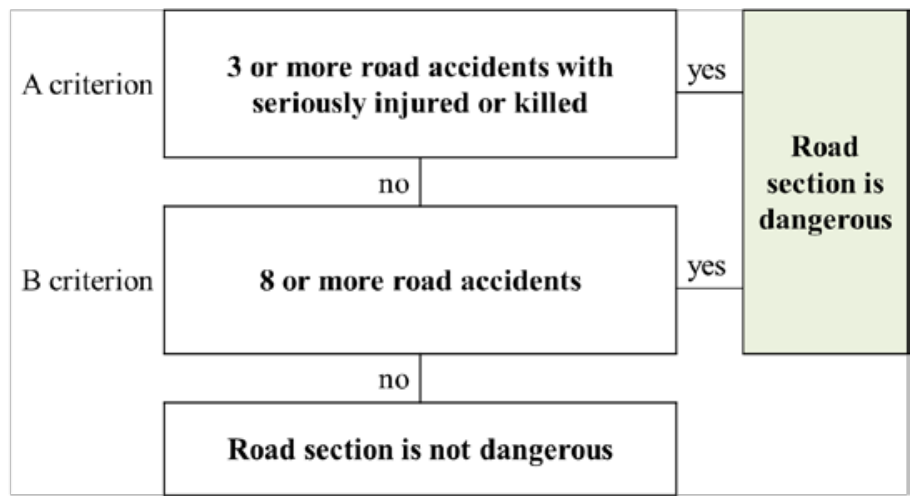

Fig. 2. Dangerous road sections and spots definition in Latvia.

Table 1. Examples of homogeneous groups of road sections and junctions.

\begin{tabular}{|c|c|c|c|c|c|c|c|c|}
\hline $\begin{array}{c}\text { Homogeneous } \\
\text { group }\end{array}$ & Type & $\begin{array}{c}\text { Speed } \\
\text { limit }\end{array}$ & $\begin{array}{c}\text { No of } \\
\text { lanes }\end{array}$ & $\begin{array}{c}\text { Width of } \\
\text { pavement }\end{array}$ & Environment & $\begin{array}{c}\text { Traffic } \\
\text { volume }\end{array}$ & Pavement & Separation \\
\hline $2+2$ road & Section & all & $>=4$ & all & Rural & all & Paved & Separated \\
\hline Urban 500-3000 & Section & 50 & 2 & all & Urban & $500-3000$ & Paved & $\begin{array}{c}\text { Not } \\
\text { separated }\end{array}$ \\
\hline $\begin{array}{c}\text { Grade separated } \\
\text { junction }\end{array}$ & Junction & all & - & all & Rural & all & Paved & Separated \\
\hline $\begin{array}{c}\text { Paved under 9m } \\
3000-6000\end{array}$ & Section & 90 & 2 & $<9 \mathrm{~m}$ & Rural & $3000-6000$ & Paved & $\begin{array}{c}\text { Not } \\
\text { separated }\end{array}$ \\
\hline $\begin{array}{c}\text { Paved over 9m } \\
3000-6000\end{array}$ & Section & 90 & 2 & $>9 \mathrm{~m}$ & Rural & $3000-6000$ & Paved & $\begin{array}{c}\text { Not } \\
\text { separated }\end{array}$ \\
\hline $\begin{array}{c}\text { Railroad } \\
\text { crossing }\end{array}$ & Junction & all & - & all & Rural & all & Paved & $\begin{array}{c}\text { Not } \\
\text { separated }\end{array}$ \\
\hline $\begin{array}{c}\text { Roundabout } \\
\text { Junction }\end{array}$ & all & - & all & Rural & all & Paved & $\begin{array}{c}\text { Not } \\
\text { separated }\end{array}$ \\
\hline $\begin{array}{c}\text { T-shape under } \\
500\end{array}$ & Junction & all & - & all & Rural & all & Paved & $\begin{array}{c}\text { Not } \\
\text { separated }\end{array}$ \\
\hline $\begin{array}{c}\text { T-shape urban } \\
\text { Junction }\end{array}$ & 50 & - & all & Urban & all & Paved & $\begin{array}{c}\text { Not } \\
\text { separated }\end{array}$ \\
\hline $\begin{array}{c}\text { X-shape urban } \\
\text { Junction }\end{array}$ & 50 & - & all & Urban & all & Paved & $\begin{array}{c}\text { Not } \\
\text { separated }\end{array}$ \\
\hline
\end{tabular}

The approach is used to identify the risk level of road sections for the whole road network. The section is considered as dangerous, if the relative risk is higher than on other sections and it does not depend on the exact value of risk calculation. In this study road sections and junctions with a level of safety $\geq 1$ were considered as dangerous road sections and junctions. 


\subsection{Data collection and processing}

All data necessary to calculate dangerous road sections and spots using three methods was prioritized. Among the first priority data were road, traffic and road accidents parameters identified as an absolute precondition to having any calculations made. The second priority data is a recommended list of additional parameters, which could be considered also for possible on-spot road safety inspections. Priority of a certain parameter differed depending on the method. If for EE methodology relatively precise road data was relevant (e.g. width of driving lanes, number of lanes, speed limit), then for Latvian methodology number of serious injuries was among the first priority data. Traffic volume on the road was a necessary parameter both for EE and LT.

In all three countries road and traffic data are stored either in road databases (EE and LV) or in the Traffic Information System (TIS) in case of LT. Estonian road administration is managing accident database, which is linked to a road database and receives road accident data directly from Police including personal data. Besides it is linked with drivers and vehicle register to have a complete dataset on each accident with casualty. Lithuanian road administration receives accident data (circumstances, vehicle data, data of accident participants, accident location, weather conditions, damages of vehicle etc.) from Police Administrative Offenses Register and stores it in TIS. Latvian road administration has an agreement with Police. According to this document, they receive some general accident data, but it is still impossible to have any specific data on people or vehicle involved in an accident because of personal data protection laws.

After gathering of all necessary and available data on road, traffic and accidents (Table 2), the calculation of dangerous E67 sections and spots was started using approaches of three Baltic countries. In order to link accident data with road and traffic data a unique ID code for each road section and intersection was generated. At the result of analysis 3 list of dangerous spots (risk performance for Estonian methodology) were composed.

Table 2. List of collected variables and parameters.

\begin{tabular}{|c|c|c|c|c|}
\hline \multicolumn{2}{|c|}{ Road and traffic data } & \multicolumn{3}{|c|}{ Accident data } \\
\hline Road section & Intersection & Accident & Participants & Vehicles \\
\hline Road number & Road number & Accident ID & Road user mode & Vehicle type \\
\hline $\begin{array}{l}\text { Address (from km to } \\
\mathrm{km} \text { ) }\end{array}$ & Address (m) & Date and hour & $\begin{array}{l}\text { Driving license } \\
\text { (yes/no) }\end{array}$ & \\
\hline AADT & $\begin{array}{l}\text { Type of } \\
\text { junction }\end{array}$ & $\begin{array}{l}\text { Number of } \\
\text { participants }\end{array}$ & Alcohol level & \\
\hline $\begin{array}{l}\text { Width of the } \\
\text { pavement (m) }\end{array}$ & $\begin{array}{l}\text { AADT on } \\
\text { minor road at } \\
\text { level crossing }\end{array}$ & Number of killed & $\begin{array}{l}\text { Type of injury } \\
\text { (injured, not } \\
\text { injured, killed) }\end{array}$ & \\
\hline $\begin{array}{c}\text { Width of the driving } \\
\text { lane }(\mathrm{m})\end{array}$ & & Number of injured & & \\
\hline Road category & & $\begin{array}{c}\text { Number of seriously } \\
\text { injured }\end{array}$ & & \\
\hline $\begin{array}{l}\text { Number of driving } \\
\text { lanes }\end{array}$ & & Accident type & & \\
\hline Speed limit $(\mathrm{km} / \mathrm{h})$ & & $\begin{array}{c}\text { Address (road } \\
\text { number, area type, } \\
\text { junction type, GPS } \\
\text { coordinates) }\end{array}$ & & \\
\hline \multirow[t]{3}{*}{$\begin{array}{l}\text { Road environment } \\
\text { (rural/urban) }\end{array}$} & & Pavement conditions & & \\
\hline & & Lighting conditions & 3 & 4 \\
\hline & & Weather conditions & 5 & 6 \\
\hline
\end{tabular}




\section{Results of the study}

As it was mentioned before, the whole Via Baltica stretch (approx. $663 \mathrm{~km}$ ) was studied with 3 methodologies (Table 3). Thus 2 lists of black sports (from LV and LT) and a list of expected number of accidents (EE) were composed for the considered corridor. Basing on LT methodology there are 19 black spots on Via Baltica: 3 in EE and 16 more in LV. There are no accidents concentration sections or spots in Lithuania itself. 53 black spots were identified by LV methodology: 12 in EE, 20 in LV and 21 in LT. These two methodologies with relatively similar approaches gave different results mainly, because LV takes into account in addition to accidents with casualties damage-only accidents. This knowledge is especially important when prioritizing black spots and making decisions on money allocation, because focus may shift from prevention of people deaths and injuries to only material losses' prevention.

Table 3. Total number of dangerous sections and spots identified by various methodologies on Via Baltica.

\begin{tabular}{|l|l|l|l|}
\hline Country & $\begin{array}{l}\text { Total number of } \\
\text { dangerous } \\
\text { locations }\end{array}$ & Length of E67, km & $\begin{array}{l}\text { Number of dangerous } \\
\text { locations per } 100 \mathrm{~km}\end{array}$ \\
\hline Estonia (EE) & 30 & 192,5 & 16 \\
\hline Latvia (LV) & 36 & 201,9 & 18 \\
\hline Lithuania (LT) & 60 & 268,4 & 22 \\
\hline Total & 126 & 662,8 & 19 \\
\hline
\end{tabular}

At the result of network safety ranking (EE methodology) totally 91 road sections and intersections could be considered as dangerous. Among them 42 are in LT, 25 in LV and 24 in EE. In this contribution a road section or intersection would be dangerous, if expected value of fatal accident was more than one. The number of dangerous sections and spots identified by each approach as well as by two and all three methodologies is given in the Table 4.

Table 4. Number of dangerous sections and spots identified by various methodologies.

\begin{tabular}{|l|l|l|l|l|}
\hline \multirow{2}{*}{$\begin{array}{l}\text { Methodology } \\
\text { used }\end{array}$} & \multicolumn{2}{|l|}{$\begin{array}{l}\text { Part of E67, where dangerous sections and } \\
\text { spots locate }\end{array}$} & \multirow{2}{*}{ Total } \\
\cline { 2 - 4 } & Estonia & Latvia & Lithuania & \\
\hline EE & 24 & 25 & 42 & 91 \\
\hline LV & 12 & 20 & 21 & 53 \\
\hline LT & 3 & 16 & 0 & 19 \\
\hline LT - LV & 3 & 16 & 0 & 19 \\
\hline LT - EE & 3 & 6 & 0 & 9 \\
\hline LV - EE & 7 & 9 & 3 & 19 \\
\hline LT - LV - EE & 3 & 6 & 0 & 9 \\
\hline
\end{tabular}

While making calculations several difficulties were met. For instance, EE and LT do not have data on seriously injured, thus LV methodology could not be used properly. Data on accidents' location in LV has insufficient accuracy: the accuracy of accidents location is 1 $\mathrm{km}$. It is impossible to determine exact location of a black spot and it may cause difficulties in case of on-spot investigation of black spots. Cross-section of some road sections in LV differed from that given in datasheet. Data on accidents' participants and vehicles was not available in LV and LT. 


\section{Conclusions and Discussion}

Within the scope of presented study, three methodologies used in the Baltic countries for dangerous road sections and spots identification were compared and the differences between them were assessed analyzing E67 EE - LV - LT corridor. In general, there are 126 dangerous sections and spots identified by three various approaches on Via Baltica. It makes approx. 19 dangerous locations per $100 \mathrm{~km}$. Estonian part of Via Baltica is the safest one considering the number of dangerous stretches and spots per $100 \mathrm{~km}$. Nine spots and stretches were pointed out as dangerous by all three methodologies.

The main difference between approaches applied in the Baltic States are following: if Latvian and Lithuanian methodologies find accidents concentration spots, Estonian methodology identifies spots where the situation is dangerous even if there were no accidents. It must be pointed out that Lithuania has no black spots on their roads identified by their own method. On the one hand, this fact may show that safety has improved on Lithuanian part of Via Baltica substantially. On the other hand, it shows that present approach has no more effect and there is a need to use more sensitive methods taking into account the test results of Estonian and Latvian methods for the same road sections. In addition to that, previous research studies [4] confirmed also that the use of such approaches as LT methodology has a great influence on the number of false positives, which increase significantly.

Also it must be mentioned that it is important for Estonian and Lithuanian approaches to have data on serious injuries available to use for network safety improvement. Latvian method takes into account in addition to accidents with casualties damage-only accidents. This becomes especially important when prioritizing black spots and making decisions on money allocation, because focus may shift from prevention of people deaths and injuries to only material losses' prevention. Although Latvian authority has to improve the accuracy of road accidents' location.

We would like to show our gratitude to Reigo Ude and Erik Ernits from the Road Safety Department of the Estonian Road Administration, Nemunas Abudauskas from the Traffic Safety Division of the Lithuanian Road Administration, Niklavs Lipins from the Traffic Management of the State Joint Stock Company Latvian State Roads for helping with data collection for this research as well as for their comments on an earlier version of the manuscript, although any errors are our own and should not tarnish the reputations of these esteemed persons.

\section{References}

1. A. Borsos, S. Cafiso, C. D’Agostino, D. Miletics, Comparison of Italian and Hungarian black spot ranking. Transportation Research Procedia 14, pp. 2148 - 2157 (2016)

2. Directive 2008/96/EC of the European Parliament and of the Council of 19 November 2008 on Road Infrastructure Safety Management. Official Journal of the European Union, Brussel, Nov., 9 p. (2008)

3. A. Erke, R. Elvik, Making Vision Zero real: Preventing pedestrian accidents and making them less severe. ТØI report 889/2007, Institute of Transport Economics, Oslo. (2007)

4. R. Elvik, State-of-the-Art Approaches to Road Accident Black Spot Management and Safety Analysis of Road Networks. TØI report 883/2007, Institute of Transport Economics, Oslo. (2007) 
5. European Commission, Towards a European road safety area: policy orientations on road safety 2011-2020. Brussel, July 2010 (2010)

6. European Commission, WHITE PAPER: Roadmap to a Single European Transport Area - Towards a competitive and resource efficient transport system. Brussel, March 2011 (2011)

7. M. Ghadia, A. Török, Comparison Different Black Spot Identification Methods. Transportation Research Procedia 27, pp. 1105-1112 (2017)

8. O.H. Kwon, M.J. Park, H. Yeo, K. Chung, Evaluating the performance of network screening methods for detecting high collision concentration locations on highways. Accident Analysis and Prevention 51, pp. 141-149 (2013)

9. M. J. Maher, L.J. Mountain, The identification of accident blackspots: A comparison of current methods. Accident Analysis and Prevention 20(2), pp. 143-151 (1988)

10. L.B. Meuleners, D. Hendrie, A.H. Lee, and M. Legge, Effectiveness of the Black spot programs in Western Australia. Accident Analysis \& Prevention 40, 1211-1216 (2008)

11. M. Sørensen, Best practice guidelines on black spot management and safety analysis of road networks. TØI report 898/2007, Institute of Transport Economics, Oslo, November 2007 (2007)

12. United Nations Development Programme, Transforming our world: the 2030 Agenda for Sustainable Development. New York (2015) 